\title{
Food Security of Urban Female-headed Households: Case in Jambi Province, Indonesia
}

\author{
Hardiani Hardiani, Junaidi Junaidi*, Purwaka Hari Prihanto
}

Economic Development Department, Faculty of Economics and Business, University of Jambi, Indonesia

\begin{tabular}{l} 
A R T I C L E I N F O \\
Research Article \\
Received 07 May 2018 \\
Accepted 19 June 2018 \\
\hline
\end{tabular}

Keywords:

Ordinal logistic

Informal sector

Food security

Household expenditure

Family structure

*Corresponding Author:

E-mail: junaidi@unja.ac.id \begin{abstract}
A B S T R A C T
This paper aims to analyze food security of urban female-headed households (FHH) in Jambi Province, Indonesia and socio-economic factors affecting food security of urban FHH in Jambi Province. Primary data is raw data from the National Socioeconomic Survey (SUSENAS) Year 2016 in regencies/cities in Jambi Province. Food security of households is analyzed descriptively. Ordinal logistic regression model is used to analyze the socio-economic factors affecting food security of urban FHH. The results of the study found that there are 12.69 percent of FHH of the total urban households in Jambi Province with urban FHH categorized as food secure is 57.62 percent, as vulnerable is 13.33 percent, as questionable is 22.38 percent, and as food insecure is 6.67 percent. Socioeconomic factors that have significant effect on food security of FHH are age, education, and employment status of female head of household, number of household members, education level of household members, and household final consumption expenditure per capita.
\end{abstract}

DOI: https://doi.org/10.24925/turjaf.v6i9.1229-1236.2007

\section{Introduction}

Food security is a situation that exists when all people, at all times, have physical, social and economic access to sufficient, safe and nutritious food that meets their dietary needs and food preferences for an active and healthy life (FAO, 2002). At the family level, poverty is a micro cause of food security issues. On the contrary, food security and nutritional status affect the improvement of quality and productivity of human resources as well as family welfare.

Family welfare is connected to the management within family. It includes structure, role, and interaction among family member. Therefore, the instability in the family both from the changes in structure, role, and interaction could affect management of family and family welfare.

One of the important phenomenon in the change of family structure is woman as the head of the family. Female-headed household (FHH) is a condition where the father dies (widowed and not remarried) or divorces (divorced and not married). The change in female-headed household structure has caused economic pressure and stress to live. Torres (1993) argues that in many developing countries, female-headed households are having a difficulty to maintain their family welfare.
In Indonesia, as one of the developing countries, this issue will increase the problems on poverty and simultaneously on food security. It is due to the rapid increase of FHH in Indonesia. In 2010, the proportion of FHH was 13.91 percent (about 8.53 million households, and it has increased to 14.63 percent in 2015 (about 9.6 million households). In other words, over the last five years there has been an increase of more than one million FHH or an increase of 2.09 percent per year (BPS, 2016; BPS, 2016a).

Jambi Province is one of the regions in Indonesia with an increasing number of FHH. In 2015, the proportion of FHH in Jambi Province was 11.03 percent. Although it is relatively smaller than the national average, the growth rate of FHH is relatively higher. During the period of 2010 - 2015, the number of FHH increased 3.23 percent per year (from 80.457 households to 93.435 households) (BPS, 2016; BPS, 2016a).

By rural-urban category, it can be seen that the proportion of FHH is larger in urban than in rural areas. In 2015 , the proportion of FHH in urban areas was 12.88 percent while in rural areas it was 10.28 percent. In addition, the growth of the number of FHH also increased more rapidly in urban areas than in rural areas. During the last five years (2010-2015), the number of FHH in urban 
areas increased by 4.36 percent per year while in rural areas it is increased by 3.72 percent per year (BPS, 2016; BPS, 2016a).

Based on the explanation above, food security of urban FHH in Jambi Province becomes an interesting issue to be analysed, with specific purposes: 1) To analyse food security of urban FHH in Jambi Province; 2) To analyse the socioeconomic factors affecting food security of urban FHH in Jambi Province.

This study is based on system theory and structuralfunctional theory. Family is the smallest social unit in society that makes up the system. The main purpose of the establishment of a family is the achievement of a welfare and life satisfaction. The quality of a system is determined by quality of its components.

Structural-functional theory is based on four concepts, namely: system, social structure, function, and equilibrium. The theory discusses how one's behaviour is influenced by others and by social institutions, and how that behaviour in turn affects others in a continuous action-reaction process. This theory sees no individual and system that functions independently but is influenced and in turn affects other people or other systems. Families tend to form a homeostatic condition. McEwen (2003) states that the term homeostasis is defined as remaining stable or staying the same.

Structure is the "arrangement of the roles of which a social system is composed" (Mclntrye 1966, referred to in Kingsbury and Scanzoni 1993). Furthermore, Mclntyre describes four factors of functionality of a family, namely "differentiated" or specialized kinds of roles, the values and norms, maintenance of boundaries (rules), and the tendency toward homeostasis or equilibrium. Kingsbury and Scanzoni (1993) explained that the roles are divided into specialized sets of activities called "instrumental" and "expressive". Instrumental activities tend to be taskoriented and are dominantly assigned to the husbandfather as the breadwinner or chief provider of the family economic needs. Expressive activities tend to be personoriented and are dominantly assigned to wife-mother that may stay at home, is responsible for emotional satisfactions of the family and focusing on integration within the family.

The balance of systems supported by performing the roles in its prime functions within the family structure will affect the achievement of family goals. The incompleteness of a family member may potentially lead to vulnerabilities of family in performing its functions, for example families with women as heads of families. Female-headed households have lower levels of work productivity compared to male-headed households (Horrell and Krishnan 2007). Joshi (2004) also points out that female-headed households have low income and asset ownership.

Furthermore, in order to analyse the determinants of food security of female-headed households, it is necessary to analyse based on various studies related to household food security level/rate (especially at FHH level and generally at the all family level, both in the rural and urban areas). Studies show that factors affecting household food security are the characteristics of the head of household (age, sex, education level, employment status) and of family (number of family members, education level and main activities of family members, family income, family expenditure). (Abafita and Kim, 2012; Sisay and Edriss, 2012; Bogale and Shimelis, 2009; Mitiku et al., 2012; Gebre ,2012; Olaniyi, 2014; Mustisya et al., 2016; Taruvinga et al., 2013; Demeke and Zeller, 2010).

\section{Research Methods}

The data used in this study are raw data from SUSENAS 2016 for all districts/cities in Jambi Province. It includes a sample of 6.096 households. There are 1.655 households in urban areas and 4.441 households in rural areas. Of the total urban households, 210 households or 12.69 percent of them are FHH.

Household food security is measured through the Jonsson and Toole's method in Maxwell et. al (2000), which is calculating the ratio of compartment expenditure on food to percentage of energy sufficiency (Ariani and Handewi, 2003). Based on this method, the result is categorized into four categories: 1) Food insecure, where the share of food expenditure is above 60 percent and energy sufficiency is below 80 percent; 2) Questionable, where the share of food expenditure is below 60 percent and energy sufficiency is below 80 percent; 3) Vulnerable, where the share of food expenditure is above 60 percent and energy consumption is above 80 percent; 4) Food secure, where the share of food expenditure is below 60 percent and energy sufficiency is above 80 percent.

Benchmark of calorie adequacy is using Regulation of the Minister of Health of the Republic of Indonesia No 75 of 2013 regarding Recommended Dietary Allowances (RDA) for Indonesian that is 2.150 kilo calories.

To analyse the socioeconomic factors affecting food security of urban $\mathrm{FHH}$, ordinal logistic regression model is used as follows:

$$
\begin{aligned}
g\left(x_{k i}\right) & =\beta_{0}+\beta_{1 . D 1} X_{1 . D 1}+\beta_{1 . D 2} X_{1 . D 2}+\beta_{1 . D 3} X_{1 . D 3}+\beta_{1 . D 4} X_{1 . D 4}+\beta_{2 . D 1} X_{2 . D 1}+\beta_{2 . D 2} X_{2 . D 2} \\
& +\beta_{3 . D 1} X_{3 . D 1}+\beta_{4 ., D 1} X_{4 . D 1}+\beta_{4 ., D 2} X_{4 . D 2}+\beta_{5 . D 1} X_{5 . D 1}+\beta_{5 . D 2} X_{5 . D 2}+\beta_{5 . D 3} X_{5 . D 3} \\
& +\beta_{6 . D 1} X_{6 . D 1}+\beta_{6 . D 2} X_{6 . D 2}+\beta_{6 . D 3} X_{6 . D 3}+\beta_{7 . D 1} X_{7 . D 1}+\beta_{7 . D 2} X_{7 . D 2}+\beta_{7 . D 3} X_{7 . D 3} \\
& +\beta_{7 . D 4} X_{7 . D 4}+e
\end{aligned}
$$

Where;

$g(x k i)=$ Level of household food security (0: Food insecure ,1: Questionable, 2: Vulnerable, 3: Food secure)

$X_{1}=$ Age of female head of household $\left(X_{1 . D 1} \quad 1=<40\right.$ years old; 0: other, $X_{1 . D 2} ; 1$ : 40-49 years old; 0: other, $X_{1 . D 3} 1=50-59$ years old; 0 ; other, $X_{1 . D 4} ; 1$ : 60-69 years old; 0; other )

$X_{2}=$ Level of formal education of female head of household (High school or above as base category: $X_{2 . D 1} 1=$ Less than Elementary School; 0: other , $X_{2 . D 2} 1$ = Junior High Scool - Senior High School; 0: other

$X_{3 . D 1}=$ Employment status of female head of household (0: unemployed/not working; 1: employed/ working)

$X_{4}=$ Number of family members (with base category $>=$ 4 persons: $X_{4 . D 1} 1=0-1$ person; 0: other, $X_{4 . D 2} 1=$ $2-3$ persons; $0=$ other) 
$X_{5}=$ Proportion of family members with high school diploma or above $(\%)$ (with base category $>75 \%$ : $X_{5 . D 1} 1=<25 \% ; 0=$ other, $X_{5 . D 2} 1=25 \%-49,99 \%$; $0=$ other, $X_{5 . D 3} 1=50 \%-74,99 \%$; $0=$ other $)$

$X_{6}=$ Proportion of family members who are employed/working (\%) (with base category > 75\%: $X_{6 . D 1} 1=<25 \% ; 0=$ other, $X_{6 . D 2} 1=25 \%-49,99 \%$; $0=$ other, $X_{6 . D 3} 1=50 \%-74,99 \%$; $0=$ other $)$

$X_{7}=$ Household final consumption expenditure per capita (IDR) (with base category >IDR. 2.000.000: $X_{7 . D 1} 1=<=500.000 ; 0=$ other, $X_{7 . D 2} 1=500.001$ $1.000 .000 ; 0=$ other, $X_{7 . D 3} 1=1.000 .001-$ $1.500 .000 ; 0=$ other, $X_{7 . D 4} 1=1.500 .001-$ $2.000 .000 ; 0=$ other)

\section{Results and Discussion}

Individual Characteristics of Female Head of Household in Jambi Province

Individual characteristics of urban female head of household can be seen from marital status, age, level of educational attainment, field of business, and employment status. Based on age, it can be argued that the average age of urban female head of household is relatively old, that is 55.96 years old. Of the frequency distribution, it shows more than three-quarters (34.29 percent) aged between 50-49 years and only 9.05 percent is less than 40 years old. In fact, there are also about 16.67 percent of them are 70 years old or above.

Based on marital status, more than two thirds (69.05 percent) of urban female head of household are those who widowed and not remarried. The large proportion of it is basically due to the average age of urban female head of household which is relatively old. Furthermore, the second largest proportion is those who are divorced and not remarried (20.00 percent).

Based on level of formal educational attainment, it can be seen that there is a relatively low level of formal educational attainment of urban female head of household. Most of them (75.24 percent) have graduated from junior high school or below. On the contrary, there are only 6.67 percent of them who have bachelor or master degree.

Not all of urban female head of household are employed. Of the total urban female head of household, 40.00 percent (84 out of 210) are not employed nor have income. This group consists of pensioners. In addition to that, they are also appointed to be head of household, although the necessities of daily life are borne by other household members (children/relatives/other).

The main field of work occupied by urban female head of household is service sector, followed by agriculture and industrial sector. Based on the employment status, the largest proportion (62.70 percent) works on informal sector. Only about one-third (37.30 percent) of them work in formal sector.

Characteristics of Family Members of Urban FemaleHeaded Household (FHH) in Jambi Province

The average number of family members of urban $\mathrm{FHH}$ (excluding head of household) was 2.15, with a share of $40.48 \%$ of households with $0-1$ person, $42.38 \%$ of households with $2-3$ persons, and the remaining (17.14\%) with 4 persons or more.
Table 1 Urban female head of household based on age in jambi province in $2016^{*}$

\begin{tabular}{l|rrr}
\hline \multicolumn{1}{c|}{ Age Group $^{* *}$} & Total & $\%$ & Cumulative \% \\
\hline$=<39$ & 19 & 9.05 & 9.05 \\
$40-49$ & 40 & 19.05 & 28.10 \\
$50-59$ & 72 & 34.29 & 62.38 \\
$60-69$ & 44 & 20.95 & 83.33 \\
$>=70$ & 35 & 16.67 & 100.00 \\
Total & 210 & 100.00 & \\
\hline Average & \multicolumn{4}{|c}{55.96} \\
\hline *Source: processed from raw data of Susenas 2016, **Years Old
\end{tabular}

Table 2 Urban female head of household based on marital status in Jambi province in $2016^{*}$

\begin{tabular}{l|ll}
\hline Marital Status & Total & $\%$ \\
\hline Never married & 7 & 3.33 \\
Married & 16 & 7.62 \\
Divorced and not remarried & 42 & 20.00 \\
Widowed and not remarried & 145 & 69.05 \\
\hline Total & 210 & 100.00 \\
\hline
\end{tabular}

*Source: processed from raw data of Susenas 2016

Table 3 Urban female head of household based on level of educational attainment in jambi province in $2016^{*}$

\begin{tabular}{l|rrr}
\multicolumn{1}{c|}{ Educational Attainment } & \multicolumn{1}{c}{ T } & \multicolumn{1}{c}{$\%$} & $\mathrm{C}$ \\
\hline N/N & 84 & 40.00 & 40.00 \\
Elementary School & 67 & 31.90 & 71.90 \\
Junior High School & 7 & 3.33 & 75.24 \\
Senior High School & 32 & 15.24 & 90.48 \\
Associate Degree (D1/D2) & 6 & 2.86 & 93.33 \\
Bachelor's Degree/Master's Degree & 14 & 6.67 & 100.00 \\
\hline Total & 210 & 100.00 & \\
\hline
\end{tabular}

*Source: processed from raw data of Susenas 2016, N/N: No schooling / Never graduated from elementary school, T: Total, C: Cumulative \%

Table 4 Urban female head of household based on field of work and employment status in Jambi province in $2016^{*}$

\begin{tabular}{l|rr}
\hline \multicolumn{3}{c}{ Tield of Work } \\
\hline Agriculture & 21 & 16.67 \\
Industry & 12 & 9.52 \\
Services & 93 & 73.81 \\
Total & 126 & 100.00 \\
\hline \multicolumn{3}{c}{ Employment Status } \\
\hline Informal & 79 \\
Formal & 47 & 62.70 \\
Total & 126 & 37.30 \\
\hline
\end{tabular}

*Source: processed from raw data of Susenas 2016

Table 5 Urban FHH based on number of family members in Jambi province in $2016^{*}$

\begin{tabular}{l|rrr}
\hline Number of Family Members & \multicolumn{1}{|c}{ T } & \multicolumn{1}{c}{$\%$} & \multicolumn{1}{c}{ C } \\
\hline $0-1$ & 85 & 40.48 & 40.48 \\
$2-3$ & 89 & 42.38 & 82.86 \\
$>=4$ & 36 & 17.14 & 100.00 \\
Total & 210 & 100.00 \\
\hline Average & \multicolumn{3}{|}{2.15} \\
\hline
\end{tabular}

*Source: processed from raw data of Susenas 2016, T: Total, C: Cumulative $\%$ 
Furthermore, the structure of family members of urban FHH is given in Table 6. From Table 6, the proportion of number of men is more than women's. Based on marital status, more than two-thirds (69.78 percent) of household members have not married, 22.44 percent of them are married, and the rest are divorced and not remarried (4.22 percent) and widowed and not remarried (3.56 percent).

Speaking of formal educational attainment, household members are relatively better than urban female heads of household. Almost half (46.42 percent) of household members are graduated from senior high school or above. 13.53 percent of them even have Bachelor's degree or Master's degree.

Based on the main activities, it can be argued that more than one-third (39.78 percent) of household members are working. The relatively large proportion shows the relatively great assurance of urban female head of household in financing daily needs. Furthermore, 28.00 percent of household members are attending school, 26.44 percent of them are having household affairs/chores as main activity, 0.22 percent of them are looking for a job, and 5.56 of them are doing other activities.

Final Consumption Expenditure per capita of Urban FHH in Jambi Province

Final consumption expenditure per capita of urban FHH in Jambi Province is IDR. 1.264.758 per month. This figure is relatively higher than the total of expenditure per capita of urban households in Jambi Province of IDR. 1.148.221 (BPS, 2017).

It shows that the welfare of urban FHH in general is relatively better compared to urban households as a whole. Nevertheless, there is a considerable imbalance among urban FHH. The standard deviation of household expenditure per capita of urban FHH reached 1.134.389, with the lowest household expenditure per capita of urban FHH is IDR. 267.110 per month and the highest is IDR. 8.182.886 per month. In addition to that, it also shows that more than half (54.29 percent) of urban FHH's expenditure per capita are less than or equal to IDR. 1.000 .000 .

\section{Food Security of Urban FHH in Jambi Province}

The level of food security of urban FHH is measured by combining two indicators of food security namely food expenditure level and the adequacy of calorie consumption. Food expenditure level can be categorized into two categories: 1) low, where the share of food expenditure is less than 60 percent of total expenditure, and 2) high, where the share of food expenditure is equal to or more than 60 percent of total expenditure. Furthermore, caloric adequacy is calculated based on minimum standard of 2.150 kilo calories per day per capita. Caloric adequacy is categorized less if the consumption is equal to or below 80 percent of the standard (2.150 kilo calories per day), and enough if more than 80 percent.

The share of urban FHH's food expenditure in Jambi Province is given in Table 8 .

The average share of food expenditure of urban $\mathrm{FHH}$ in Jambi Province in 2016 was 49.15 percent, with the lowest of 11.48 percent and the highest of 86.38 percent, and standard deviation of 12.55. This figure is higher than the average share of food expenditure of households in Jambi Province as a whole which is 45.60 percent (BPS, 2017). Furthermore, speaking of calorie consumption, average calorie consumption of urban FHH in Jambi Province has been relatively good, with the figure reaching 103.92 percent higher than the standard of 2.150 kcal per capita per day. The lowest calorie consumption rate was 47.16 percent and the highest was 216.67 percent with a standard deviation of 35.72 percent. Based on the distribution, it shows that only 29.05 percent of FHH are insufficient $(<=80$ percent $)$ and most of them are sufficient ( $>80$ percent).

Table 6 Structure of household/family members of urban FHH in Jambi province in $2016^{*}$

\begin{tabular}{l|rr}
\hline \multicolumn{2}{c}{ Structure of Household Members } & $\%$ \\
\hline \multirow{3}{*}{ Mex } & Male & 52.44 \\
& Female & 47.56 \\
\hline & Have not married & 69.78 \\
& Married & 22.44 \\
& Divorced and not remarried & 4.22 \\
& Widowed and not remarried & 3.56 \\
\hline \multirow{5}{*}{ Educational Attainment } & No schooling / Never graduated from elementary school & 14.32 \\
& Elementary School & 22.55 \\
& Junior High School & 16.71 \\
& Senior High School & 27.59 \\
& D1/D2 (Associate Degree) & 0.27 \\
& D3 (Associate Degree) & 5.04 \\
& S1-S2 (Bachelor's - Master's Degree) & 13.53 \\
\hline \multirow{5}{*}{ Main Activities } & Working & 39.78 \\
& Attending school & 28.00 \\
& Household Affairs & 26.44 \\
& Looking for a job & 0.22 \\
& Others & 5.56 \\
\hline
\end{tabular}

\footnotetext{
*Source: processed from raw data of Susenas 2016
} 
Table 7 Distribution of urban FHH based on expenditure per capita in Jambi province in $2016^{*}$

\begin{tabular}{|c|c|c|c|}
\hline Expenditure per capita & Total & $\%$ & Cumulative $\%$ \\
\hline$<=500.000$ & 30 & 14.29 & 14.29 \\
\hline $500.001-1.000 .000$ & 84 & 40.00 & 54.29 \\
\hline $1.000 .001-1.500 .000$ & 43 & 20.48 & 74.76 \\
\hline $1.500 .001-2.000 .000$ & 29 & 13.81 & 88.57 \\
\hline$>2.000 .000$ & 24 & 11.43 & 100.00 \\
\hline Total & 210 & 100.00 & \\
\hline Minimum & & 267.110 & \\
\hline Maximum & & 8.182 .886 & \\
\hline Standard Deviation & & 1.134 .389 & \\
\hline Average & & 1.264 .758 & \\
\hline
\end{tabular}

*Source: processed from raw data of Susenas 2016

Table 8 Distribution of urban FHH based on share of food expenditure in Jambi province in $2016^{*}$

\begin{tabular}{l|rr}
\multicolumn{1}{c|}{ Share of Food Expenditure } & Total & $\%$ \\
\hline Low $(<60$ percent) & 168 & 80.00 \\
High $(>=60$ percent) & 42 & 20.00 \\
Total & 210 & 100.00 \\
\hline Minimum & & 11.48 \\
Maximum & & 86.38 \\
Standard deviation & & 12.55 \\
Average & 49.15 & \\
\hline
\end{tabular}

*Source: processed from raw data of Susenas 2016

Table 9 Distribution of urban FHH based on calorie adequacy in Jambi province in 2016

\begin{tabular}{l|rr}
\multicolumn{1}{c}{ Adequacy of Calorie Consumption } & Total & $\%$ \\
\hline Insufficient (<=80 percent) & 61 & 29.05 \\
Sufficient (> 80 percent) & 149 & 70.95 \\
Total & 210 & 100.00 \\
\hline Minimum & & 47.16 \\
Maximum & & 216.67 \\
Standard deviation & & 35.72 \\
Average & 103.92 & \\
\hline
\end{tabular}

*Source: processed from raw data of Susenas 2016

Based on the share of food expenditure and the adequacy of calorie consumption, urban FHH can be classified based on the level of food security. Table 10 shows that 57.62 percent of FHH are categorized as food secure. Only about half of them are having low share of food consumption and sufficient calorie consumption.

13.33 percent of them are categorized as vulnerable. In this group, although its calorie consumption is sufficient, the share of food expenditure is still high. 22.38 percent of $\mathrm{FHH}$ are categorized as questionable, which is, although the share of food expenditure is low, the calorie consumption is still low. The lowest proportion of 6.67 percent is $\mathrm{FHH}$ in food insecure category. FHH in this group are having high share of food expenditure, but the calorie consumption is classified as insufficient.

Socioeconomic Factors Affecting Food Security of Urban FHH in Jambi Province

Goodness of fit model: Goodness of Fit model using Deviance method aims to see if the obtained ordinal logistic regression model is feasible to use. Deviance shows how much variation that can't be explained by the logistic regression model. The higher the deviance value the less accurate its model.

Hypothesis:

Ho: logit model is fit/feasible to use

$\mathrm{H} 1$ : logit model is not fit/feasible to use
With criteria:

Reject Ho if significant value of Deviance is less than $\alpha=0.05$

Accept Ho if significant value of Deviance is larger than or equal to $\alpha=0.05$.

Based on Table 11, the value of Chi-Square of Deviance method is 279.591 , with significant value of 1.00. Because it is greater than $\alpha=0.05$, the decision taken is to accept Ho. Thus, the conclusion is that the logit model obtained is fit/feasible to use.

Model Fitting: Model fitting is done by comparing model without predictor variable (intercept only model) and model with predictor (final model). Given the following results of model fitting:

Hypothesis:

Ho: $\beta 1=\beta 1=\beta p=0$ or model containing only the intercept is fit/suitable to use

$\mathrm{H} 1$ : there is at least one $\beta p \neq 0$ or model containing only the intercept is not fit/suitable to use

With the criteria:

Reject Ho if the statistical significance of $\mathrm{G}$ (ChiSquare) is less than $\alpha=0.05$

Accept Ho if the statistical significance of $\mathrm{G}$ (ChiSquare) $>=\alpha=0.05$.

Based on Table 12, the value of -2 Log Likelihood in intercept only model is 434.652 and in final model is 301.920. The statistical value of $\mathrm{G}$ (Chi-Square) is 132.732 with a significance of 0.000 . The significant 
value is smaller than $\alpha=0.05$, so the decision taken is to reject Ho. Thus, the conclusion is that there is one $\beta p \neq 0$ or a suitable model is a model with predictor/final model.

Wald Test and Interpretation Model: The result of Wald test (Table 13) shows that out of 7 variables, 6 of them have a significant effect on food security level of urban FHH in Jambi Province. Significant variables are age of female head of household (except for $<=39$ years old age group), educational attainment of female head of household, working status/main activities of female head of household, number of household members, educational attainment of household members, and household final consumption expenditure per capita (except household expenditure per capita group of IDR. 1,501,000 $2,000,000)$. On the other hands, the variable that has no significant effect is main activities of household members.

Table 10 Distribution of Urban FHH based on food security categories in Jambi province in $2016^{*}$

\begin{tabular}{|c|c|c|c|}
\hline Categories of Food Security & Total & $\%$ & Cumulative $\%$ \\
\hline Food Insecure & 14 & 6.67 & 44.06 \\
\hline Questionable & 47 & 22.38 & 86.71 \\
\hline Vulnerable & 28 & 13.33 & 93.71 \\
\hline Food Secure & 121 & 57.62 & 100.00 \\
\hline Total & 210 & 100.00 & \\
\hline
\end{tabular}

*Source: processed from raw data of Susenas 2016

Table 11 Goodness of fit model

\begin{tabular}{l|ccc}
\hline & Chi-Square & df & Sig. \\
\hline Pearson & 449.456 & 497 & 0.938 \\
Deviance & 279.591 & 497 & 1.000 \\
\hline
\end{tabular}

Table 12 Model fitting information

\begin{tabular}{|c|c|c|c|c|}
\hline Model & -2 Log Likelihood & Chi-Square & $\mathrm{df}$ & Sig. \\
\hline Intercept Only & 434.652 & & & \\
\hline Final & 301.920 & 132.732 & 19 & 0.000 \\
\hline
\end{tabular}

Table 13 Estimation of parameter model and wald test

\begin{tabular}{|c|c|c|c|c|c|c|}
\hline & & Estimate & S.E & Wald & Sig. & Odds rasio \\
\hline \multirow{4}{*}{ Y } & Food Insecure & -7.134 & 1.449 & 24.235 & 0.000 & \\
\hline & Questionable & -4.382 & 1.393 & 9.892 & 0.002 & \\
\hline & Vulnerable & -3.369 & 1.381 & 5.951 & 0.015 & \\
\hline & Food Secure & $\mathrm{a}$ & & & & \\
\hline \multirow{5}{*}{ Age (years) } & $<40$ & -1.096 & 0.871 & 1.585 & 0.208 & 0.334 \\
\hline & $40-49$ & -1.684 & 0.701 & 5.779 & 0.016 & 0.186 \\
\hline & $50-59$ & -0.970 & 0.597 & 2.639 & 0.100 & 0.379 \\
\hline & $60-69$ & -1.607 & 0.604 & 7.072 & 0.008 & 0.201 \\
\hline & $70+$ & $\mathrm{a}$ & & & & \\
\hline \multirow{3}{*}{ Educational attainment } & Less than Elementary School & -1.128 & 0.659 & 2.933 & 0.087 & 0.324 \\
\hline & Elementary - Junior High School & -1.225 & 0.593 & 4.264 & 0.039 & 0.294 \\
\hline & Senor High School and higher & $\mathrm{a}$ & & & & \\
\hline \multirow{2}{*}{$\begin{array}{l}\text { Working/Employment } \\
\text { Status }\end{array}$} & Not Working & -0.771 & 0.456 & 2.865 & 0.091 & 0.462 \\
\hline & Working & $\mathrm{a}$ & & & & \\
\hline \multirow{3}{*}{$\begin{array}{l}\text { Number of Household } \\
\text { Members }\end{array}$} & $0-1$ & 1.509 & 0.585 & 6.658 & 0.010 & 4.520 \\
\hline & $2-3$ & 1.199 & 0.449 & 7.133 & 0.008 & 3.315 \\
\hline & $>=4$ & $\mathrm{a}$ & & & & \\
\hline \multirow{4}{*}{$\begin{array}{l}\% \text { of Household Members } \\
\text { Graduating from Senior } \\
\text { High School }\end{array}$} & $<25$ & 1.691 & 0.786 & 4.626 & 0.031 & 5.427 \\
\hline & $25-49,99$ & 1.860 & 0.766 & 5.888 & 0.015 & 6.422 \\
\hline & $50-74,99$ & 1.188 & 0.697 & 2.907 & 0.088 & 3.280 \\
\hline & $>75$ & $\mathrm{a}$ & & & & \\
\hline \multirow{4}{*}{$\begin{array}{l}\% \text { of Household Members } \\
\text { Working }\end{array}$} & $<25$ & 0.079 & 0.718 & 0.012 & 0.912 & 1.082 \\
\hline & $25-49,99$ & 0.295 & 0.650 & 0.206 & 0.650 & 1.343 \\
\hline & $50-74,99$ & -0.099 & 0.495 & 0.040 & 0.841 & 0.906 \\
\hline & $>75$ & $\mathrm{a}$ & & & & \\
\hline \multirow{5}{*}{$\begin{array}{l}\text { Expenditure per capita } \\
\text { (IDR) }\end{array}$} & $<=500.000$ & -6.538 & 1.282 & 25.996 & 0.000 & 0.001 \\
\hline & $500.001-1.000 .000$ & -3.967 & 1.163 & 11.630 & 0.001 & 0.019 \\
\hline & $1.000 .001-1.500 .000$ & -2.291 & 1.159 & 3.905 & 0.048 & 0.101 \\
\hline & $1.500 .001-2.000 .000$ & -0.719 & 1.299 & 0.307 & 0.580 & 0.487 \\
\hline & $>2.000 .000$ & $\mathrm{a}$ & & & & \\
\hline
\end{tabular}


Furthermore, the ordinal logit regression model is interpreted by observing the significance and value of the odds ratios of each variable. Based on the figures above, it could tell:

- Age of urban female head of household: There is no opportunity difference of urban female head of household who is less than 40 years old than those who is 70 years old or older (as base category) in getting categorized as food secure. It is shown from the insignificance of Wald test on those age groups.

There are significant effects on age group of 40-49, 50-59, and 60-69. Odds ratio that is smaller than 1 means that FHH with female head of household in these age groups have a lower chance of reaching food secure level than FHH with female head of household aged 70 years old or above.

Urban FHH with female head of household aged 4049 have a chance of 0.186 times to reach food secure level than those with female head of household aged 70 years old or above. Those with female head of household aged 50-59 years old have a chance of 0.376 times and those with female head of household age 70 years old or above. It suggests that the chances of achieving food secure level are greater for relatively young age group and older age group of female head of household.

- Educational attainment of urban female head of household: The higher the educational attainment of urban female head of household the higher their chances to achieve food secure level. FHH with female head of household having educational attainment below primary school have chances of 0.324 times and those graduating from primary middle school have chances of 0.295 times to achieve food secure level compared to those graduating from senior high school or above (as base category).

- Employment status / Working status of urban female head of household: FHH with unemployed female head of household have a lower probability $(0.462$ times) to reach food secure level compared to those with employed female head of household.

- Number of Household Members: The smaller the number of household members, the greater the chances of FHH to reach food secure level. FHH with 0-1 children have a chance of 4.52 times and with 2-3 children have a chance of 3.315 times to reach food secure level compared to FHH with 4 or more children (as base category).

- Educational attainment of household members: Educational attainment of household members has a significant effect on the possibility or urban FHH to become food-secure households. It is shown from the significant variables of the proportion of household members graduating from senior high school.

However, directions influence of this variable is not as expected as to be. Urban FHH with a relatively small proportion of household members graduating from senior high school have an opportunity to become food-secure households compared to those with a larger proportion of household members graduating from senior high school. It is shown that the odds ratio of the proportion of household members graduating from senior high school <25\%, $25-49.99 \%$, and 50$74.99 \%$ are greater than 1 . It means that these three groups have a greater opportunity to reach food secure level than those with the proportion of household members graduating from senior high school $>75 \%$.

- Main Activities of Household Members: There is no significant effect by proportion of household members working on the chances of getting food secure status in urban FHH in Jambi Province.

- Household Final Consumption Expenditure per capita: The greater the expenditure per capita, the higher the chances of household becoming foodsecure households. FHH with the expenditure per capita of IDR 500.000 or less have a chance of 0.001 times to reach food secure level compared to those with expenditure per capita of IDR. 2.000.000 (as base category).

Furthermore, FHH with expenditure per capita of IDR. $500.001-1.000 .000$ have a chance of 0.19 times, of IDR. 1.000.001 - 1.500.000 have a chance of 0.101 times to reach food secure level compared to those with expenditure per capita of above IDR. 2.000.000. Nevertheless, there is no difference in the chances between FHH with expenditure per capita of IDR. 1.500.001 - 2.000.000 compared to those with expenditure per capita of above IDR. 2.000.000.

\section{Conclusion and Suggestion}

This paper aims to analyse food security of urban female-headed households and socio-economic factors that influence it in Jambi Province, Indonesia. The results of the study found that: 1) Of the total urban households in Jambi Province, there are 12.69 percent of femaleheaded households $(\mathrm{FHH})$; 2) The proportion of urban FHH in Jambi Province that is categorized as food secure is 57.62 percent, as vulnerable is 13.33 percent, as questionable is 22.38 percent, and as food insecure is 6.67 percent; 3) Socioeconomic factors that have significant effect on food security of FHH are age, education, and employment status of female head of household, number of household members, education level of household members, and household final consumption expenditure per capita.

The well-being of urban female-headed household (FHH) in Jambi Province is relatively good, but there are still almost half of FHH that are not categorized as food secure. Therefore, it is necessary to have policies related to the direction or consumption patterns in urban FHH in particular and to households in the province in general. Furthermore, at the theoretical level, for further research it is advisable to add macro-scale variables (eg aspects of area, culture, policy) as variables affecting food security.

\section{References}

Abafita J, Kim KR. 2012. Determinants of Household Food Security in Rural Ethiopia: An Empirical Analysis. Journal of Rural Development. 37(2): 129-157

Bogale A, Shimelis A. 2009. Household Level Determinants of Food Insecurity in Rural Areas of Dire Dawa, Eastern Ethiopia. African Journal of Food Agriculture Nutrition and Development. 9 (9): 1914-1926 
BPS. 2016. Persentase Rumah Tangga menurut Provinsi Daerah Tempat Tinggal, dan Jenis Kelamin Kepala Rumah Tangga, 2009 - 2017 https://www.bps.go.id/statictable/2012/04/19/ 1604/persentase-rumah-tangga-menurut-provinsi-daerahtempat-tinggal-dan-jenis-kelamin-kepala-rumah-tangga2009-2017.html

BPS. 2016a. Banyaknya Rumah Tangga menurut Provinsi, 2000 -2015. https://www.bps.go.id/dynamictable/2015/09/07/851/ banyaknya-rumah-tangga-menurut-provinsi-2000-2015.html

Demeke AB, Zeller M. 2010. Impact of Rainfall Shock on Smallholders Food Security and Vulnerability in Rural Ethiopia: Learning from Household Panel Data. Retrieved from http :// Econpapers.repec.org/paper/agsuhohdp.

FAO. 2002. The State of Food Insecurity in the World 2001. Rome: FAO

Gebre GG. 2012. Determinants of Food Insecurity Among Households in Addis Ababa City, Ethiopia. Interdisciplinary Description of Complex Systems. 10(2): 159-173

Horrell S, Krishnan P. 2007. Poverty and productivity in femaleheaded households in Zimbabwe. Journal of Development Studies. 43(8): 1351-1380

Joshi S. 2004. Female household-headship in rural Bangladesh: incidence, determinants and impact on children's schooling. Center Discussion Paper No. 894.

Kingsbury N, Scanzoni J. 1993. Structural-functionalism. In P. G. Boss, W. J. Doherty, R. LaRossa, W. R. Schumm, \& S. K. Steinmetz (Eds.), Sourcebook of family theories and methods: A contextual approach (pp. 195-217). New York: Plenum.

Maxwell D, Levin C, Kiemeseu MA, Rull M, Morris S, Aliadeke C. 2000. Urban Livelihoods and Food and Nutrition Security, in Greater Accra Ghana. Research Report No. 112 Wahington DC: IFPRI
McEwen B, Lasley EN. 2003. “All stressed out? Here's what to do about it”. Consumers' Research Magazine 29: 10-13.

Mitiku A, Fufa B, Tadese B. 2012. Empirical Analysis of the Determinants of Rural Household Food Security in Southern Ethiopia: The Case of Shashemene District. Basic Research Journal of Agricultural Science and Review. 1(6):132-138

Mutisya M, Ngware MW, Kabiru CW. 2016. The effect of education on household food security in two informal urban settlements in Kenya: a longitudinal analysis. Food Sec. 8:743-756.

Olaniyi OA. 2014. Assessment of household's food access and food insecurity in urban Nigeria: a case study of Lagos Metropolis. Glob J Hum SocSciEco.14(1): 20-30.

Olayemi AO. 2012. Effects of family size on household food security in Osun State, Nigeria. Asian J Agr Rural Develop. 2(2): 136-141.

Sisay E, Edriss AK. 2012. Determinants of Food Insecurity in Addis Ababa City, Ethiopia. Journal of Economics and Sustainable Development. 3 (3): $8-15$

Taruvinga A, Muchenje V, Mushunje A. 2013. Determinants of rural householddietary diversity: the case of Amatole and Nyandeni district, South Africa. Int J Dev Sustain. 2(4): 115.

Torres AT. 1993. Coping strategies of female-headed households in urban poor communities of the philippines. Research report, presented at the Fourth Women in Asia Conference, University of Melbourne, Melbourne Australia.

Winton CA. 1995. Framework for Studying Families. The Duskin Publishing Group, Inc. Guilord, Connecticut. 